\title{
Influence of Macroeconomic Variables on Exchange Rates
}

\author{
Ravindran Ramasamy and Soroush Karimi Abar
}

\begin{abstract}
Exchange rates play a significant role in international trade not only in fixing the prices but also in determining the nature of hedging to be arranged to avoid exchange rate risks. In this article we used three countries yearly exchange rates with their macroeconomic variables such as relative interest rates etc to study the impact they exert on exchange rates. We used bootstrapping technique to increase the sample size to run regression to study the effect. The previous researchers used general regression models to establish relationships but we have applied multi models by linking complementary variables to identify the best model. Our results showed that model B was robust which indicated all macroeconomic variables significantly influenced the exchange rates except employment and budget deficit. Most of the macroeconomic variables showed opposite sign contrary to the expectations and we concluded that the psychological factors like investor confidence dominate over economic variables in deciding exchange rate fluctuation.
\end{abstract}

Index Terms-Bootstrapping, exchange rate, hedging, inflation rate, interest rate.

\section{INTRODUCTION}

Exchange rate fluctuation or stability is the major concern which determines the quantum and direction of foreign trade and commerce [1].

Exchange rate (XR) fluctuation and its effect on the volume of international trade is an important subject for empirical investigation, after the adoption of floating exchange rate 1973. Exchange rate fluctuation is defined as the risk associated with unpredicted movements in exchange rate. Macroeconomic variables such as interest rate, inflation rate, the balance of payments, tax rate etc influence the XR randomly. These macroeconomic variables are unstable and volatile depending on the state of the economy prevailing in their countries [2]. In addition increased cross border currency flows due to foreign direct investment and service like banking, insurance, education, tourism cause the exchange rate fluctuate randomly. Advent of on line trading, currency speculation is rampant and cause exchange rates to fluctuate.

The role of XR in imports and exports is crucial. In addition a country's overall economic performance is reflected by XR [3]. Macroeconomic variables prevail in home and host countries determine the exchange rate equilibrium in long-run. Short-run fluctuations are temporary caused by arrival of economic information from time to time from home and host countries. Increasingly the incoming and outgoing foreign direct investments create massive capital

Manuscript received September 16, 2013; revised November 20, 2013.

The authors are with the Graduate School of Business University Tun Abdul Razak, Malysia (e-mail: ravindran@unirazak.edu.my, soroush.karimi87@gmail.com). flows and directly influence XR. Even counties which follow floating rate and non intervention policy sometimes feel uncomfortable when the XR become volatile. Fluctuations of XR have significant impact on countries' import and export behavior [4] and ultimately culminate in current account balance and foreign currency reserves held by the central banks.

Recent global economic turmoil affected significantly different systems of economy. Exchange rate is not an exception as it is closely aligned to macroeconomic variables. Country with an appreciating home currency will experience its goods become more expensive in international market which may affect the exports and at the same time imports become inexpensive [5]. This is a double blow to the home country which will rapidly affect the BOP. In contrast if domestic currency depreciates, imports will be expensive in the domestic market and local companies would find their goods more attractive due to lower prices in international markets.

XR not only influences imports, exports and direct investments but also several service sectors like banking, insurance, education, tourism. In addition consolidation of financial statements of foreign subsidiaries with domestic parent also becomes cumbersome. While translating foreign subsidiary financial statements in home currency the exchange rates paly the spoil shot. XRs extensively deflate or inflate profit and asset values of the foreign subsidiary as the opening and closing XRs substantially differ, thereby creating a situation where mandatory manipulation is permissible which ultimately results in wrong reporting. The pertinent example is Enron.

The Asian economic crisis caused by currency depreciation in the late 90 s and the recent sub-prime loan crisis of 2008 eroded not only market capitalization of companies but also severely strained the national economies [6]. To bailout the distressed companies the governments used tax payers' money in the hope of recovering the amount spent in future once these organizations stabilize. To bridge the gap, the governments increase the tax rates and also bring in new taxes such as service tax and surcharges. These measures bring in some disparity and imbalance in economic alignment which affect the exchange rates ultimately. This prompted to investigate the role of relative interest rates (IR), inflation rates (IFR) and a host of economic variables of home and host countries in determining the XRs.

This paper is organized as follows: section one introduces the topic and discuses the importance of XRs, section two explains the relationship between exchange rate and important macroeconomic variables. Section three explains the methodology and data while section four discusses the results obtained by analysis. Section five concludes the paper. 


\section{XR AND MACROECONOMIC VARIABLES}

Home and host countries' interest rates play a significant role in exchange rate determination. The interest rates are adjusted quarterly by the central bank as part economic management. If inflationary pressure prevails in the country, the central bank will increase base lending rate to curtail the money supply among the people and companies to make borrowings expensive. Assuming the host country does not adjust the interest rate, this increase in one country creates inequilibrium in demand and supply for money and in turn it causes the exchange rate to move to equilibrium. If not arbitrage profits are possible in borrowing and investing between countries. If both home and host countries simultaneously increase or decrease the interest rates matching, then there will be no effect on exchange rate due to interest rate. The relative interest rate is an important factor which influences XRs.

This increase in the general price level of goods and services in an economy is inflation, measured by the Consumer Price Index. In other words price raise is inflation and the same is depreciation of home currency in international parlance. When the home inflation rate is high the home currency will lose value and vice versa. Inflation and exchange rate are negatively correlated. A country with lower inflation exhibits a rising currency value and vice versa Exchange rate hike indicates the loss of home currency value.

The balance of payments (BOP) is a net indicator of outflow and inflow of foreign currencies. Outflows and inflows are caused by international trade and services [7]. The BOP comprises current account and financial account. The current account includes merchandise, services, interest, dividends, unilateral transfers and errors and omissions. The inflows are credited and outflows are debited to this current account and finally the resulting net balance indicates the surplus or deficit generated in a year. The financial account records the FDIs and the portfolio investments' inflows and outflows. Both these accounts jointly determine the foreign exchange reserves available in a country [8]. The floating rate regime countries will not use these reserves at the times of crisis in exchange rate while countries which follow managed float will use this to regulate the exchange rate by suitably releasing foreign currencies required from this reserve [9].

Relationship between the employment rate and exchange rate is unclear because the employment rate can be quantified in several ways. Underemployment issue is a challenge that could not be quantified with accuracy. The service sector is another problem area which uses manpower. The services cannot be stored and idle time quantification is problematic. If the home currency depreciates there will be an increased demand for home country's goods in foreign countries which leads to more production in home country and thus leads to more employment and vice versa [10].

The national governments should spend within the national income by collecting tax. If expenditure exceeds the revenue the governments will finance the gap by borrowing or by printing currency notes. These actions erode the confidence of the external parties who have financial dealings with the home country. If the governments fail to raise finance by taxes they go in for foreign debt. Foreign debts and budget deficit create financial imbalance which leads to exchange rate fluctuation [11].
Corruption surfaces at lower rungs of society due to poverty, poor standard of living prevailing in a country. In contrast the rich indulge in corrupt practices to accumulate wealth as it satisfies their ego and increases the political and muscle power in a society. The ineffective legal system, and lenient or lack of punishment for corrupt practices also increases corruption. Due to corruption the economic system of a country is severely impaired and cost of doing business in that country increases. The first blow is received by the infrastructure of that country. Substandard materials, lengthy operating procedures, bureaucratic delay by government officials, lengthy legal battles are the consequences of corruption. There is a positive relationship between corruption and exchange rate which leads to depreciation of home currency. Corruption also results in insecurity and fixed costs for the international trade in the form of extortion and bribes which ultimately affects the exchange rates.

Multinational companies establish subsidiary companies in other countries to reduce their cost of production as the input costs are cheaper in the host countries. These produce goods in large volume and export. This results in massive cash flows which affect XRs [12].

\section{Methodology}

This study investigates nine important macroeconomic variables' relationship and their influence on exchange rates. Regression modeling technique is widely applied to estimate coefficients for independent variables, to test hypotheses and to evaluate the importance of each independent variable in the model. Following the same path this article also uses the following theoretical model to assess the importance macroeconomic variables.

$$
y=a+\beta_{i} x_{i}+\ldots+\beta_{n} x_{n}+\varepsilon, \quad i=1, \ldots, n .
$$

where

$$
\begin{aligned}
& y=\text { Exchange rate } \\
& a=\text { Intercept } \\
& \beta=\text { Regression coefficient to be estimated } \\
& x=\text { Independent variable } \\
& i=\text { List of independent variables } \\
& x_{1}=\text { Relative interest rates } \\
& x_{2}=\text { Relative inflation rate } \\
& x_{3}=\text { Relative balance of payments } \\
& x_{4}=\text { Relative employment rate } \\
& x_{5}=\text { Relative corruption index } \\
& x_{6}=\text { Relative gross domestic product } \\
& x_{7}=\text { Relative deficit/surplus rate } \\
& x_{8}=\text { Relative tax rate } \\
& x_{9}=\text { Relative borrowing rate }
\end{aligned}
$$

When a country's GDP is less the government will face a deficit in its budget which will lead for higher tax rates to collect more revenue. If public resents the governments will borrow locally by issuing bonds or from foreign financial institutions to bridge the gap. These actions will inflation. These variables are closely linked and complementary and therefore a multi modeling technique is adopted to clearly see the effect of these variables by linking them as follows.

Model A will be the traditional model which will include all the nine variables together 
Model B will link the GDP and budget deficit as they are complementary

Model C will link the GDP, budget deficit and tax rate

Model D will link the GDP, budget deficit, tax rate and borrowing

Model E will link the GDP, budget deficit, tax rate and inflation

The above five models are tested in AMOS software and their fit indices are assessed by Chi-Square and Root mean squared error approximation (RMSEA).

\section{DATA}

To test the above models exchange rates AUD/USD, Euro/USD, AUD/Euro are considered. These XRs are considered because United States, Australia and Germany (representative for Euro) are strong economies with minimum unemployment, less corrupt and lesser deficit in their budgets. These counties faced the recent global economic crisis more or less on the same level. Data regarding the macroeconomic variables were collected from the central banks of respective countries. To model the independent and dependent variables the sample size is to be larger. Time series annual data was collected for ten years which yielded only 30 data samples. Hence to augment the sample size the data is bootstrapped to 200. This is acceptable because for most of the economic variables the data is published annually. Even after collecting 10 years of data only ten samples are available for each country.

\section{RESUlTS AND DisCUSSION}

Inflation rate shows minus mean for AUD and Euro. The Australian inflation rate has declined steeply from 5.039 percent and Euro inflation also has declined but marginally. When AUD and Euro are compared the inflation has not declined instead it has increased by 2.35 percent. The other variable with the minus sign is the deficit/surplus. The Australian deficit financing has declined marginally. The BOP for Euro and for AUD also show negative balances which indicate that these countries imports are more than the exports by 1.203 and 1.067 percentages respectively. The standard deviation for inflation is also high when compared to the other variables for AUD/USD. It is 19.314 percent and for Euro/USD and AUD/Euro are 2.335 and 2.413 percent respectively.

TABLE I: DESCRIPTIVE STATISTICS OF XRS AND RELATIVE ECONOMIC VARIABLES

\begin{tabular}{|c|c|c|c|c|c|c|}
\hline & \multicolumn{2}{|c|}{ AUD/USD } & \multicolumn{2}{|c|}{ Euro/USD } & \multicolumn{2}{|c|}{ AUD/EURO } \\
\hline & Mean & Std. Dev & Mean & Std. Dev & Mean & Std. Dev \\
\hline Exchange rate & 1.224 & 0.180 & 0.768 & 0.058 & 1.591 & 0.183 \\
\hline Interest rate & 1.471 & 0.227 & 0.909 & 0.105 & 1.633 & 0.305 \\
\hline Inflation rate & -5.039 & 19.314 & -0.036 & 2.335 & 2.358 & 2.413 \\
\hline BOP & 1.074 & 0.207 & -1.203 & 0.478 & -1.067 & 0.630 \\
\hline GDP & 0.167 & 0.025 & 1.010 & 0.141 & 0.168 & 0.036 \\
\hline Tax Rate & 1.390 & 0.083 & 0.899 & 0.091 & 1.559 & 0.161 \\
\hline Borrowings & 0.232 & 0.023 & 0.900 & 0.068 & 0.260 & 0.038 \\
\hline Deficit/surplus & -0.061 & 0.446 & 0.345 & 0.304 & 2.349 & 3.587 \\
\hline Employment rate & 1.035 & 0.036 & 0.989 & 0.062 & 1.048 & 0.029 \\
\hline
\end{tabular}

Exchange rate is influenced by all macroeconomic variables which push or pull the exchange rate different ways. Among these nine variables which one is the most important significant variable is the subject matter of this study. Fig. 1 and Fig. 2 depict the model specification in the traditional regression form with co-variances. Fig. 1 gives co-variances and unstandardized coefficients of regression. Fig. 2 gives the standardized regression coefficients of all variables.

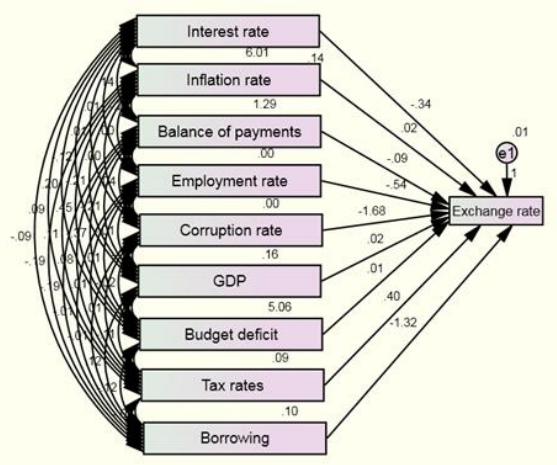

Fig. 1. Unstandardized coefficients

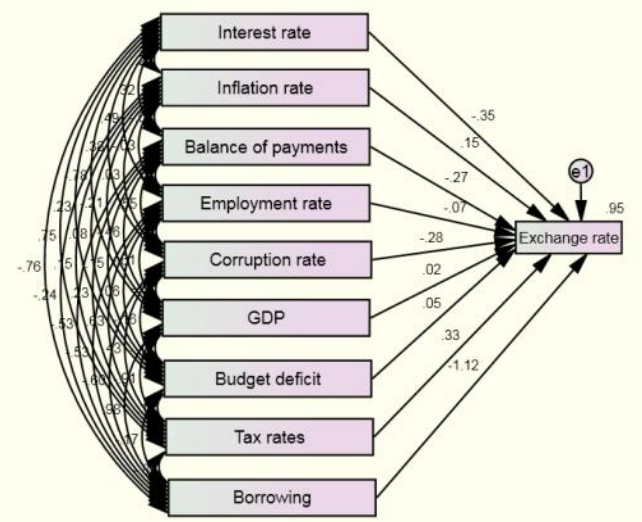

Fig. 2. Standardized coefficients

Model A includes all variables in its equation without restricting any item. The unstandardized coefficients show the influence of each variable on the exchange rate. Interest rate is a significant variable which if increases by one the XR will go down by 0.339 . 
TABLE II: REGRESSION ESTIMATES OF MODEL A

\begin{tabular}{|c|c|c|c|c|c|c|c|}
\hline & Unstandardized & S.E. & C.R. & Sig & Label & Standardized & $\overline{R^{2}}$ \\
\hline Interest & -0.339 & 0.070 & -4.825 & $* * *$ & $a$ & -0.349 & 0.946 \\
\hline Inflation & 0.022 & 0.008 & 2.851 & 0.004 & $b$ & 0.150 & \\
\hline BOP & -0.088 & 0.026 & -3.388 & $* * *$ & $c$ & -0.273 & \\
\hline Employment rate & -0.535 & 0.466 & -1.148 & 0.251 & $d$ & -0.072 & \\
\hline Corruption & -1.684 & 0.424 & -3.976 & $* * *$ & $e$ & -0.278 & \\
\hline GDP & 0.020 & 0.277 & 0.071 & 0.943 & $f$ & 0.022 & \\
\hline Deficit/Surplus & 0.008 & 0.008 & 0.940 & 0.347 & $g$ & 0.048 & \\
\hline Tax & 0.399 & 0.180 & 2.213 & 0.027 & $h$ & 0.328 & \\
\hline Borrowing & -1.315 & 0.350 & -3.756 & $* * *$ & $i$ & -1.118 & \\
\hline
\end{tabular}

The corruption variable is another significant variable which also shows a negative relationship with XR. If corruption increases by $100 \%$ the exchange rate drops by $168.4 \%$. Similarly the BOP influences the exchange rate significantly. The other variables are contributing to XR in a meager way as they are insignificant. The standardized coefficients indicate the relative importance of independent variables in the model. Borrowings, interest rate and tax rate are the highly influential variables.

TABLE III: REGRESSION ESTIMATES OF MODEL B

\begin{tabular}{|c|c|c|c|c|c|c|c|}
\hline & Unstandardized & S.E. & C.R. & Sig & Label & Standardized & $\overline{R^{2}}$ \\
\hline Interest & -0.340 & 0.068 & -4.972 & $* * *$ & $a$ & -0.350 & 0.946 \\
\hline Inflation & 0.022 & 0.008 & 2.870 & 0.004 & $b$ & 0.150 & \\
\hline BOP & -0.088 & 0.026 & -3.442 & $* * *$ & $c$ & -0.273 & \\
\hline Employment rate & -0.541 & 0.450 & -1.202 & 0.229 & $d$ & -0.073 & \\
\hline Corruption & -1.692 & 0.388 & -4.363 & $* * *$ & $e$ & -0.279 & \\
\hline GDP & 0.008 & 0.008 & 0.941 & 0.346 & $f$ & 0.009 & \\
\hline Deficit/Surplus & 0.008 & 0.008 & 0.941 & 0.346 & $f$ & 0.048 & \\
\hline Tax & 0.397 & 0.176 & 2.26 & 0.024 & $h$ & 0.326 & \\
\hline Borrowing & -1.303 & 0.206 & -6.310 & $* * *$ & $i$ & -1.108 & \\
\hline
\end{tabular}

In model B, GDP and deficit financing are linked together as they are very closely related. When GDP is more the deficit will be less and vice versa. Instead of having two complementary independent variables they are linked together and the model is run as model B. GDP and deficit financing show the same values for regression coefficients (0.008), standard error (0.008), critical ratio (0.941), significance $(0.346)$ but slightly differ in standardized coefficients (0.009 and 0.048). The standardized coefficient GDP is reduced from $2.2 \%$ to less than $1 \%(0.9 \%)$. All variables are significant except employment rate which may be unconnected to exchange rate.

When the GDP is low to fulfill the expenditure gap the deficit financing is applied and the tax rates are increased to collect more revenue. Hence these three variables are closely linked together. As such they are linked to take the same values in model $\mathrm{C}$. The $R^{2}$ slightly goes down from the original model $(94.6 \%$ to $93.7 \%$ ). This proves these variables could be linked to be parsimonious. In addition in the previous models these variables were insignificant and in this model also they are insignificant after linking them as one variable.

TABLE IV: REGRESSION ESTIMATES OF MODEL C

\begin{tabular}{|c|c|c|c|c|c|c|c|}
\hline & Unstandardized & S.E. & C.R. & Sig & Label & Standardized & $R^{2}$ \\
\hline Interest & -0.311 & 0.073 & -4.273 & $* * *$ & $a$ & -0.320 & 0.937 \\
\hline Inflation & 0.016 & 0.008 & 1.998 & 0.046 & $b$ & 0.104 & \\
\hline BOP & -0.123 & 0.022 & -5.566 & $* * *$ & $c$ & -0.380 & \\
\hline Employment rate & -0.315 & 0.475 & -0.664 & 0.507 & $d$ & -0.042 & \\
\hline Corruption & -1.906 & 0.407 & -4.681 & $* * *$ & $e$ & -0.315 & \\
\hline GDP & 0.002 & 0.009 & 0.242 & 0.809 & $f$ & 0.002 & \\
\hline Borrowing & -1.700 & 0.116 & -14.668 & $* * *$ & $i$ & -1.446 & \\
\hline
\end{tabular}

If deficit and tax collections are low the government will go in for borrowings to sustain. On this assumption all four variables are linked in model $\mathrm{D}$ to assess the impact of other variables on exchange rate. The $R^{2}$ drops drastically to $45.6 \%$ and most of the variables become insignificant except inflation. 
TABLE V: REgRESSION ESTIMATES OF MODEL D

\begin{tabular}{|c|c|c|c|c|c|c|c|}
\hline & Unstandardized & S.E. & C.R. & Sig & Label & Standardized & $\overline{R^{2}}$ \\
\hline Interest & 0.311 & 0.175 & 1.776 & 0.076 & $a$ & 0.321 & 0.456 \\
\hline Inflation & 0.054 & 0.022 & 2.494 & 0.013 & $b$ & 0.361 & \\
\hline BOP & 0.019 & 0.058 & 0.331 & 0.740 & $c$ & 0.060 & \\
\hline Employment rate & 2.082 & 1.314 & 1.584 & 0.113 & $d$ & 0.280 & \\
\hline Corruption & -0.261 & 1.153 & -0.226 & 0.821 & $e$ & -0.043 & \\
\hline GDP & 0.021 & 0.025 & 0.845 & 0.398 & $f$ & 0.023 & \\
\hline
\end{tabular}

Model E is under the assumption that the budget deficit and borrowings are closely connected to inflation and as such inflation is linked to model D variables. This model produces poor results. The $R^{2}$ further drops to $43.6 \%$ and all variables become insignificant except inflation. This model fit is poor.

TABLE VI: REGRESSION ESTIMATES OF MODEL E

\begin{tabular}{|c|c|c|c|c|c|c|c|}
\hline & Unstandardized & S.E. & C.R. & Sig & Label & Standardized & $R^{2}$ \\
\hline Interest & 0.311 & 0.178 & 1.746 & 0.081 & $a$ & 0.321 & 0.436 \\
\hline Inflation & 0.040 & 0.017 & 2.350 & 0.019 & $b$ & 0.267 & \\
\hline BOP & 0.019 & 0.060 & 0.327 & 0.744 & $c$ & 0.060 & \\
\hline Employment rate & 1.958 & 1.332 & 1.470 & 0.142 & $d$ & 0.263 & \\
\hline Corruption & 0.008 & 1.142 & 0.007 & 0.995 & $e$ & 0.001 & \\
\hline GDP & 0.040 & 0.017 & 2.350 & 0.019 & $b$ & 0.044 & \\
\hline
\end{tabular}

The fit indices of various models are given below. The AIC and BCC suggest that the model B fit is ideal. In addition the RMSEA is 0.000 for this model while others show poor fit with higher RMSEA. To substantiate this, the $\mathrm{R}^{2}$ is very high at $94.6 \%$ for this model.

TABLE VII: FIT INDICES OF DIFFERENT MODELS

\begin{tabular}{|c|c|c|c|c|c|c|c|}
\hline Model & CMIN & DF & $\mathrm{P}$ & CMIN/DF & RMSEA & AIC & $\mathrm{BCC}$ \\
\hline Model A & - & - & - & - & - & 110.000 & 177.222 \\
\hline Model B & 0.002 & 1 & 0.966 & 0.002 & 0.000 & 108.002 & 174.002 \\
\hline Model C & 4.670 & 2 & 0.097 & 2.335 & 0.215 & 110.670 & 175.448 \\
\hline Model D & 67.221 & 3 & - & 22.407 & 0.859 & 171.221 & 234.777 \\
\hline
\end{tabular}

\section{CONCLUSION}

In this research three economically sound relatively less unemployment and less corrupt countries XRs are chosen to investigate. Interestingly many variables show the opposite relationships. For instance, interest rate, BOP and inflation rates should influence the exchange rate positively as per theory but the results show the opposite. We interpret this as true for these reasons; firstly the currency values of these countries are fairly stronger, the strength comes from confidence of public and investors and not from economic variable prevailing in these countries. Secondly the independent variables have complex interrelationships and interactions among themselves which may not be captured by a weak traditional regression model. Thirdly these countries' economies are fairly corrupt free, stable in interest rates and least unemployment rates prevail, hence the model gives diametrically opposite results. This may be due to the inclusion of macroeconomic variables ignoring the psychological factor which is the confidence of investors and traders on the performance or stability of these economies.

\section{REFERENCES}

[1] F. Allen and D. Gale, "Competition and financial stability," Journal of Money, Credit, and Banking, pp. 433-480, 2004

[2] E. Kocenda and J. Valachy, "Exchange rate volatility and regime change: A visegrad comparison," Journal of Comparative Economics, pp. $727-753,2006$

[3] A. C. Arize, T. Osang, and D. J. Slottje, "Exchange rate volatility and foreign trade: Evidence from thirteen LDCs," Journal of Business and Economics Statistics, pp. 10-17, 2000

[4] K. L. Wang and C. B. Barrett, "Estimating the Effects of Exchange Rate Volatility on Export Volumes," Journal of Agricultural and Resource Economics, pp. 225-255, 2007

[5] C. Sauer and A. K. Bohara, "Exchange rate volatility and exports: Regional differences between developing and industrialized countries," Review of International Economics, 2001

[6] G. Corsetti, P. Pesenti, and N. Roubini, "What caused the asian currency and financial crisis?" Japan and the World Economy, pp. 305-373, 1999

[7] A. J. Makin, "International economics, finance and trade," The Balance of Payments and the Exchange Rate, vol. I, 2004

[8] S. Tenreyro, "On the trade impact of nominal exchange rate volatility," Journal of Development Economics, pp. 485-508, 2007

[9] A. R. Ghosh, A. M. Gulde, and H. C. Wolf, Exchange Rate Regimes: Choices and Consequences, The MIT Press, 2003

[10] H. Duncan, "The effect of exchange rate volatility on trade and employment: A brief review of the literature economics," Macroeconomy, Economic Bias and Employment, vol. 28, no. 3, pp. 133-152, 2001 
[11] G. Schnabl, "The Russian currency basket: Recent developments in Russia's exchange rate policies and the role of the Euro," Intereconomics, pp. 135-141, 2006

[12] A. C. Arize, J. Malindretos, and K. M. Kasibhatla, "Does exchange rate volatility depress flows: The case of LDCs," International Advances in Economic Research, pp. 7-19, 2003

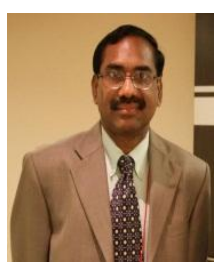

Ravindran was born at Tiruvannamalai, Tamil Nadu, India, on 14-05-1956. He completed his M.Com (accountancy and taxation specializations) at University of Madras. Later he obtained M.Phil., and $\mathrm{Ph} . \mathrm{D}$ at the same university. He completed his MBA under IGNOU, a famous Indian open university. He passed CIMA professional exam with a third rank in world in one of the accounting papers. $\mathrm{He}$ is an associate member of CIMA. He published many articles on quantitative finance and won a best paper award for presenting a paper on valuation of collateralized debt obligations (CDOs) at a Sydney conference in 2009. Presently he is working at University Tun Abdul Razak as professor of accounting and finance.

His research interests are in the area of derivatives, their pricing mechanisms, assessing their risk in combination with the underlying and hedge the risk they possess in both individual and portfolio construct.

Soroush the second author has completed his MBA at University Tun Abdul Razak, and pursuing his $\mathrm{PhD}$ in the finance area. 